\title{
Evaluation of Thermal Behavior of the Skeleton in a Green Building with the Aid of TABS
}

\author{
Hiroshi Muramatsu ${ }^{1, *}$, Tatsuo Nobe ${ }^{1}$ \\ ${ }^{1}$ Kogakuin University, Department of Architecture, 1-24-2, Nishi-Shinjuku, Shinjuku-ward, Tokyo, Japan
}

\begin{abstract}
In this study, an office building in Japan that incorporates energy-saving features and environmental technologies was investigated. This office building features a green façade, natural ventilation, a concrete slab with no suspended ceilings, and thermo-active building systems. Two airconditioning systems were installed in this building - a ceiling radiation air-conditioning system and a whole floor-blow off air conditioning system. In addition, a natural ventilation system was installed. We surveyed the heat flux of the ceiling surface and indoor thermal environment of this building from 2015 through 2016. The ceiling using the heat storage amount of concrete maintains a constant temperature in the workplace during as well as after office hours. We also performed detailed measurements of the heat flux of the ceiling surface and indoor thermal environment in the summer of 2017. The results showed that the ceiling radiation air-conditioning system provided a stable thermal environment. Furthermore, we report that making use of the thermal behavior of the skeleton improved the operation of the ceiling radiation airconditioning system.
\end{abstract}

\section{Introduction}

On March 11, 2011, the Great East Japan Earthquake occurred. Ceilings fell in many buildings, and restrictions on power consumption forced offices to cut back on lighting and air conditioning. As a result, offices that did not contain windows that opened became problematic.

This study investigates the integration of the latest green building technologies into buildings, so that they make the most of the lessons learned from the earthquake. The building in our study features a green façade, natural ventilation, a concrete slab with no suspended ceilings, and thermo-active building systems (TABS).

The floor plan of the building has an open hallway along the windows as a "perimeter aisle", and the building has a green façade. These function as a thermal buffer zone. The occupants walking along the perimeter aisle can enjoy the greenery and have easy access to windows and blinds.

Two air-conditioning systems were installed in this building - a ceiling radiation air-conditioning system and a whole floor-blow off air-conditioning system.

The ceiling radiation air-conditioning system employs a reverse slab structure. In this system, ceiling radiation is performed by allowing cold or hot water to flow through a pipe buried in a ceiling slab. The radiation airconditioning system employs a ceiling consisting of a concrete slab with a large thermal capacity; this raises the comfort and stability of the indoor thermal environment. Some windows can be opened or closed by an automatic operating system based on the indoor and outdoor temperature and humidity. In addition, the windows are automatically opened and closed during the early morning without any manual operation necessary. Therefore, the concrete ceiling with large thermal capacity can perform heat storage of early-morning cool air.

This building was highlighted with the aid of TABS. In Europe, TABS have been installed in many buildings since the late 1990s (Olesen, 2012). However, in Japan, TABS have been installed in only a few buildings. The authors surveyed the heat flux of the ceiling surface and indoor thermal environment of this building from 2015 through 2016. The ceiling uses the heat storage amount of concrete and maintains a constant temperature in the workplace during as well as after office hours.

We also performed more detailed measurements of the heat flux of the ceiling surface and indoor thermal environment in the summer of 2017. The results showed that the ceiling radiation air-conditioning system provided a stable thermal environment. In addition, we report that making use of the thermal behavior of the skeleton improved the operation of the ceiling radiation air-conditioning system.

\section{Methods}

\subsection{Building Summary}

Table 1 lists information on the studied building. Figure 1 shows the east side view of the building, which is located in an urban area of Tokyo. Owing to the urban heat island phenomenon, the outside temperature may

\footnotetext{
* Corresponding author: muramatsu@nikken.jp
} 
often exceed $35^{\circ} \mathrm{C}$ in summer. However, in winter, it may drop to nearly $0{ }^{\circ} \mathrm{C}$. In the intermediate period when the outside temperature is near $20^{\circ} \mathrm{C}$, natural ventilation is effective.

Table 1. Building Summary

\begin{tabular}{|c|c|}
\hline Building name & Coop Kyosai Plaza \\
\hline Location & Tokyo, Japan \\
\hline Lot Area & $1556.80 \mathrm{~m}^{2}$ \\
\hline Total Floor Area & $8652.86 \mathrm{~m}^{2}$ \\
\hline Number of stories & $\begin{array}{c}8 \text { stories above ground and } 2 \\
\text { stories below ground }\end{array}$ \\
\hline Structure & $\begin{array}{c}\text { Base Isolating Device and Base } \\
\text { Isolating Foundation Structure }\end{array}$ \\
\hline $\begin{array}{c}\text { Completion of } \\
\text { construction }\end{array}$ & April, 2015 \\
\hline
\end{tabular}

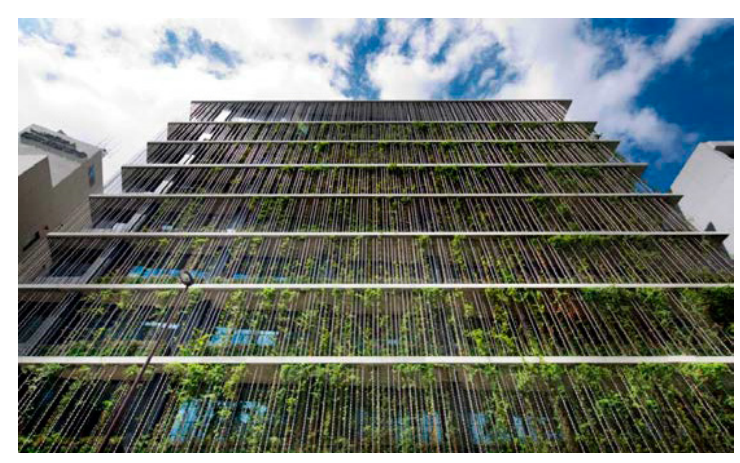

Fig. 1. East side view of the building

This building incorporates various energy-saving features and environmental technologies, which are shown in Figure 2. Figure 3 shows the green façade and balcony of this building. These function as solarradiation shields. Figure 4 shows the solar water heater installed in the roof. Solar heat is converted into cool water by an adsorption refrigerator.

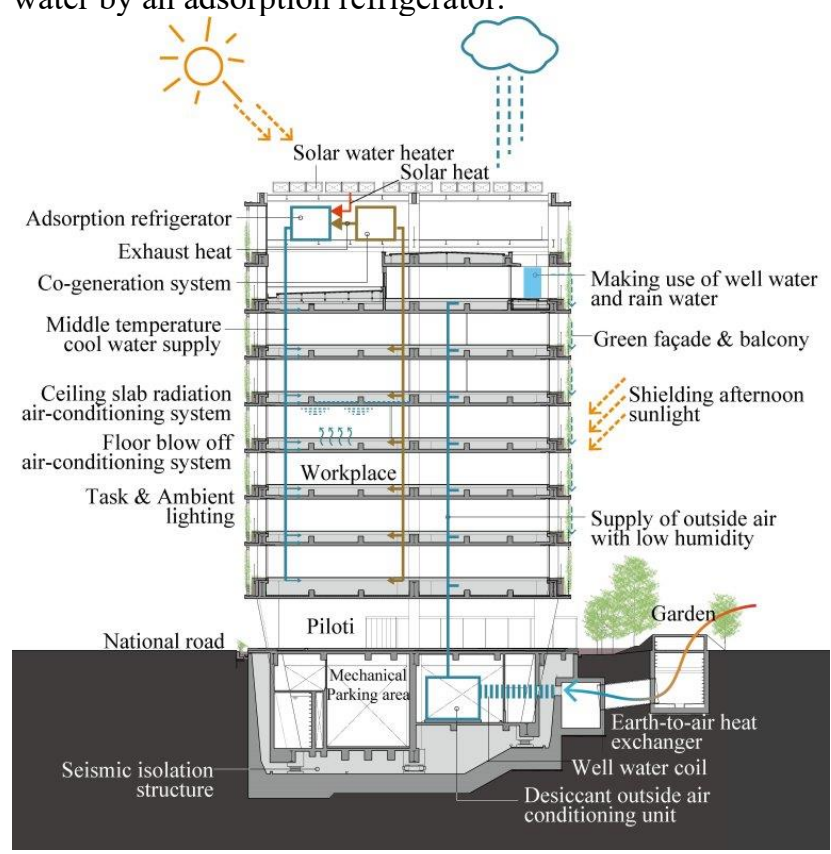

Fig. 2. Environmental technologies of the building

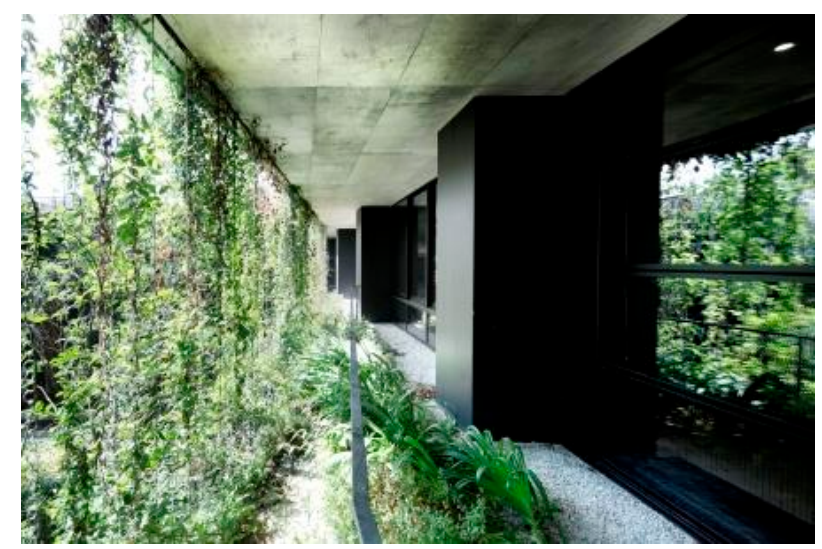

Fig. 3. The green façade and balcony

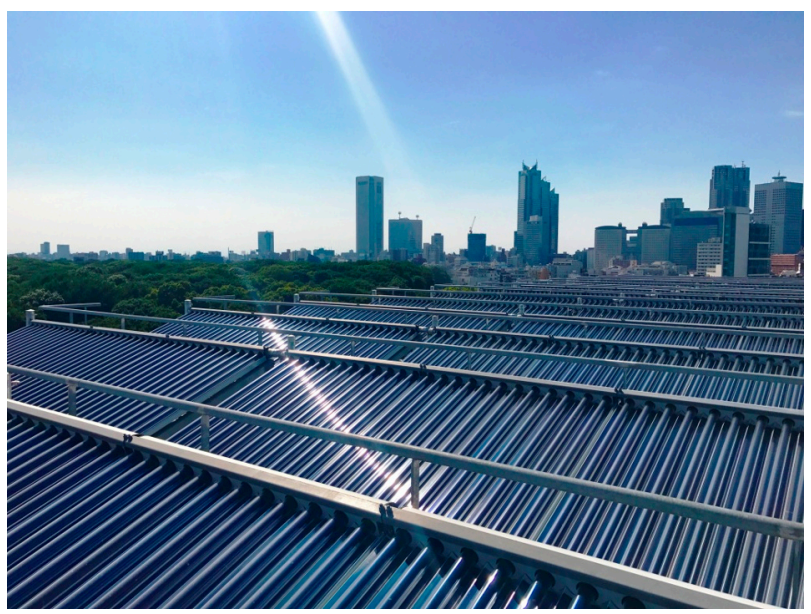

Fig. 4. Solar water heater

\subsection{Air-conditioning systems}

Figure 5 shows the air-conditioning systems, and Figure 6 shows a ceiling slab and underfloor space.

The ceiling radiation air-conditioning system uses the reverse slab structure. In this system, ceiling radiation is performed by allowing cold or hot water to flow through a pipe buried in a ceiling slab. Using the underfloor space occupied by the reverse slab structure, the whole floor-blow off air conditioning system is formed by installing a fan coil unit under the floor. The floor plan of the building has an open hallway along the windows as a "perimeter aisle" and a green façade. These function as a thermal buffer zone. Therefore, an air-conditioning system for perimeter zones is not necessary. Figure 7 show the view of the interior during office hours.

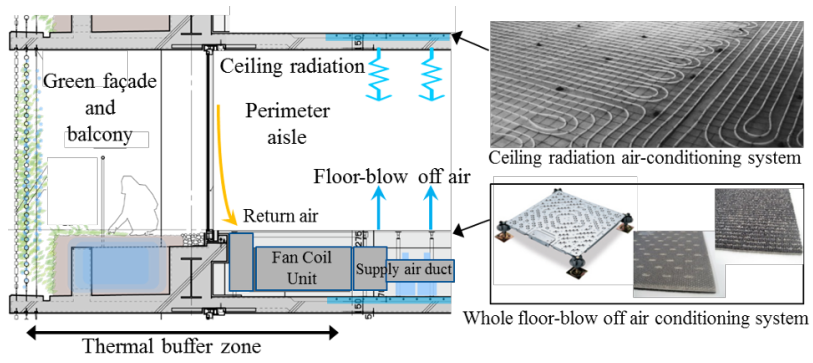

Fig. 5. Air-conditioning systems 


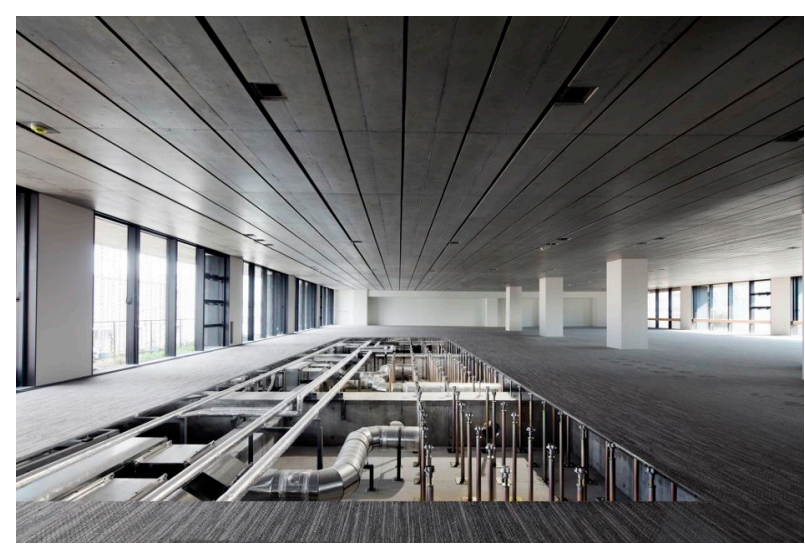

Fig. 6. View of a concrete ceiling and underfloor space

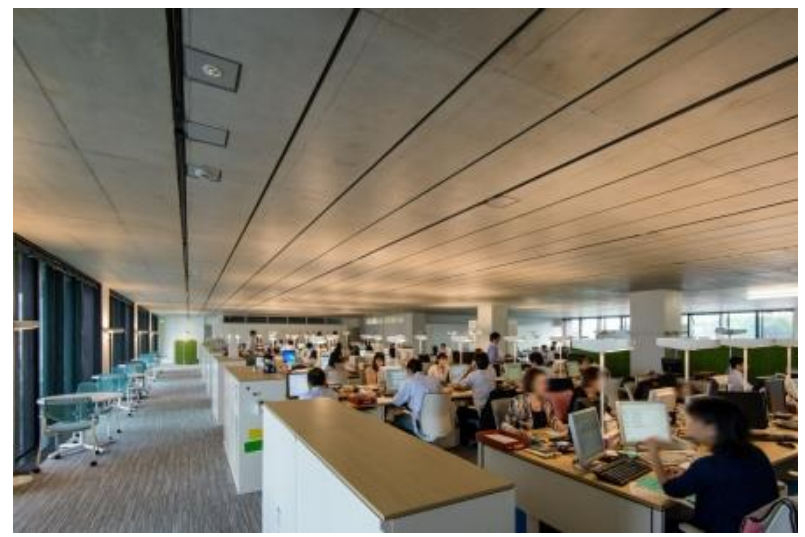

Fig. 7. View of the interior during office hours

\subsection{Natural ventilation system}

Figure 8 shows the plan of this building, and Figure 9 shows the windows of this building.

The natural ventilation system in this building operates by automatically opening and closing four windows installed on each floor. These windows are opened and closed automatically, based on the temperature and humidity inside and outside the room, outside wind velocity, and the presence of rain. Fifteen windows are installed that are manually opened and closed by an office worker. When the natural ventilation system is in operation, the air-conditioning systems are switched off.

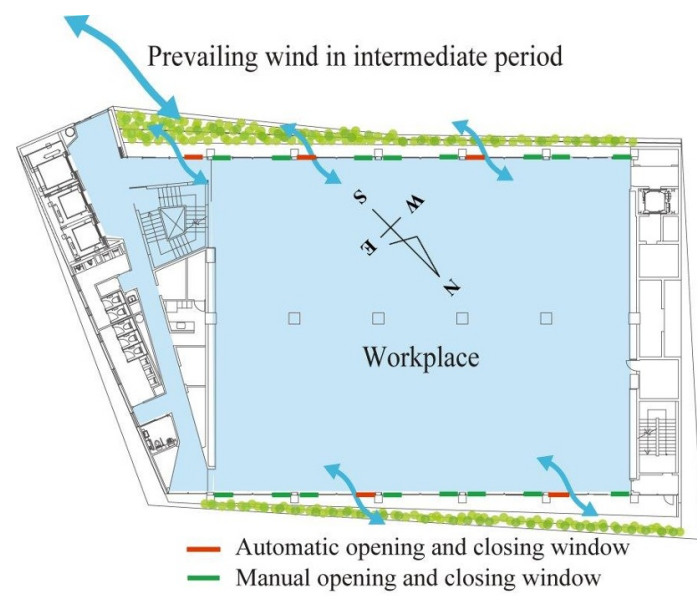

Fig. 8. Plan of this building

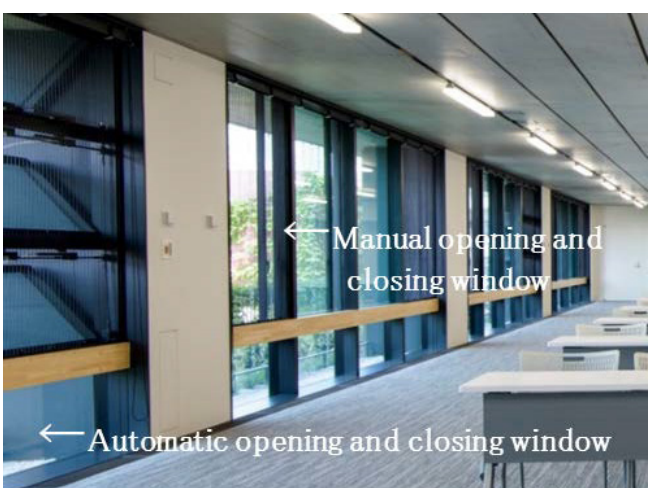

Fig. 9. Windows of this building

\subsection{Measurement}

Figure 10 shows the measurement points, while Table 2 shows the measurement periods. Table 3 summaries the measuring devices.

To measure the environment inside the structure, thermal environmental measuring devices for air temperature, globe temperature, relative humidity, and air speed were placed on desks. Devices measuring the vertical temperature distribution were placed in the interior zone, east perimeter zone, and west perimeter zone. Meters used to measure the heat flux of the ceiling surface were placed in the interior and on the east and west perimeter of the ceiling surface.

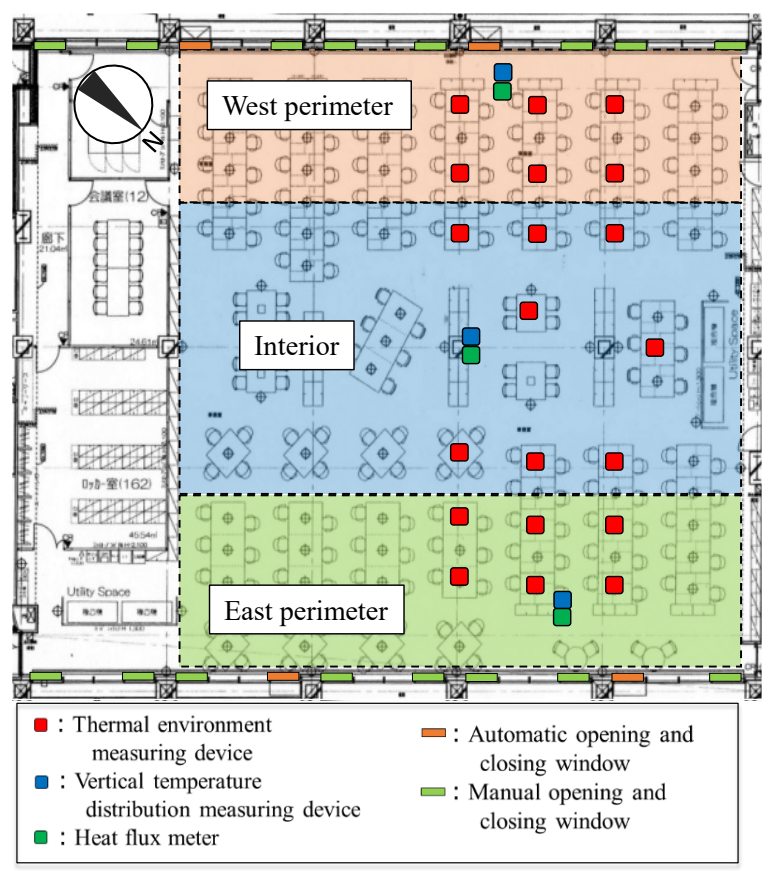

Fig. 10. Measurement Points

Table 2. Measurement periods

\begin{tabular}{|c|c|}
\hline \multirow{2}{*}{ Summer } & $\begin{array}{c}\text { Aug. } 17^{\text {th }}-\text { Sept. } 14^{\text {th }}, 2015 \\
\text { July } 21^{\text {st }}-\text { Aug. } 17^{\text {th }}, 2016 \\
\text { Aug. } 21^{\text {st }}-\text { Sept. } 15^{\text {th }}, 2017\end{array}$ \\
\hline Intermediate period & $\begin{array}{c}\text { Oct. } \text { st }^{\text {st }} \text { Oct. } 30^{\text {th }}, 2015 \\
\text { Oct. } 3^{\text {rd }}-\text { Oct. } 28^{\text {th }}, 2016\end{array}$ \\
\hline Winter & $\begin{array}{c}\text { Dec. } 21^{\text {st }}, 2015-\text { Jan. } 14^{\text {th }}, 2016 \\
\text { Dec. } 26^{\text {th }}, 2016-\text { Jan. } 11^{\text {th }}, 2017\end{array}$ \\
\hline
\end{tabular}


Table 3. Measuring devices

\begin{tabular}{|c|c|c|c|}
\hline $\begin{array}{c}\text { Device } \\
\text { name }\end{array}$ & $\begin{array}{c}\text { Thermal } \\
\text { environment } \\
\text { measuring } \\
\text { device }\end{array}$ & $\begin{array}{c}\text { Vertical } \\
\text { temperature } \\
\text { distribution } \\
\text { measuring } \\
\text { device }\end{array}$ & $\begin{array}{c}\text { Heat flux } \\
\text { meter }\end{array}$ \\
\hline $\begin{array}{c}\text { Appear } \\
\text { ance }\end{array}$ & & & \\
\hline $\begin{array}{c}\text { Installa } \\
\text { tion }\end{array}$ & $\begin{array}{c}\text { Personal desk } \\
\text { Workplace }\end{array}$ & $\begin{array}{c}\text { Ceiling } \\
\text { surface }\end{array}$ \\
\hline $\begin{array}{c}\text { Air temp.: } \\
5 \text { min } \\
\text { Meas. }\end{array}$ & $\begin{array}{c}\text { Globe temp.: } \\
5 \text { min } \\
\text { Humidity: } \\
5 \text { min } \\
\text { Air speed } \\
1 \text { min }\end{array}$ & $\begin{array}{c}\text { Vertical } \\
\text { distribution: } \\
5 \text { min }\end{array}$ & Heat flux: \\
& & \\
& & \\
\hline
\end{tabular}

\section{Results}

\subsection{Thermal environment}

\subsubsection{Indoor temperature}

Figure 11 shows the average values of the indoor and outside temperature in summer. In summer, the average air temperature in operating air-conditioning systems during office hours was $26.7^{\circ} \mathrm{C}$. The temperature difference between the perimeter and interior was less than $1{ }^{\circ} \mathrm{C}$. After office hours, when the air conditioner was switched off, the indoor temperature was stable near $26^{\circ} \mathrm{C}$ because of the use of thermal capacity.

Figure 12 shows the average values of the indoor and outside temperature in winter. The average indoor temperature in operating air-conditioning systems during office hours was $24.7^{\circ} \mathrm{C}$. The temperature difference between the perimeter and interior was less than $0.5^{\circ} \mathrm{C}$. After office hours, when the air conditioner was switched off, the indoor temperature decreased by approximately $2{ }^{\circ} \mathrm{C}$. It was confirmed that the thermal environment was very stable during both summer and winter, because the thermal capacity of this building is large.

Figure 13 shows the average values of the indoor temperature, outdoor temperature, and window opening rate for the natural ventilation system in operation. The automatic opening and closing windows were left open from 6:00 to 9:00, and the indoor temperature decreased by approximately $2{ }^{\circ} \mathrm{C}$. Afterwards, the indoor temperature rose slowly, but stayed near $27^{\circ} \mathrm{C}$, and the window opening rate was approximately $20 \%$. It was confirmed that the indoor temperature was relatively stable when the natural ventilation system was operational during office hours.

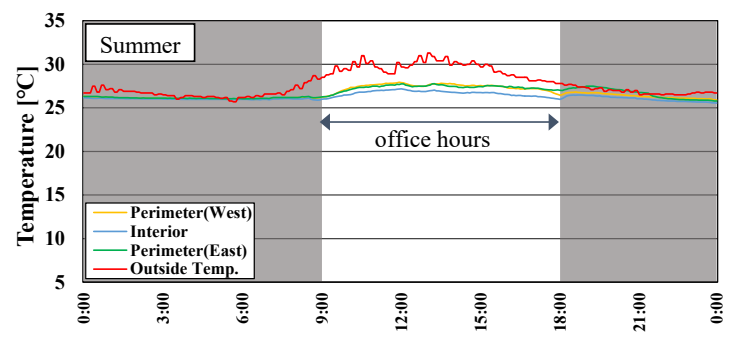

Fig. 11. Indoor and outdoor temperature in summer

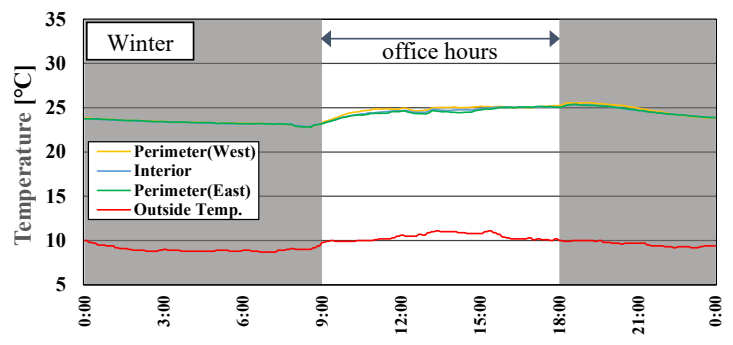

Fig. 12. Indoor and outdoor temperature in winter

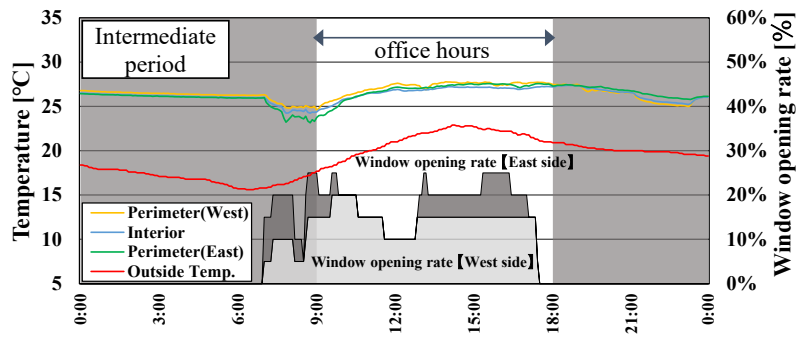

Fig. 13. Indoor temperature, outdoor temperature and window opening rate in operating the natural ventilation system.

\subsubsection{Vertical temperature distribution}

Figure 14 shows the vertical temperature distribution in summer, winter, and the intermediate period. In summer, the temperature near the ceiling was approximately $24.5^{\circ} \mathrm{C}$ during office hours, as the ceiling radiation air conditioning was operated such that the ceiling surface temperature reached $22^{\circ} \mathrm{C}$. The temperature at the other height was near $26^{\circ} \mathrm{C}$, and the vertical temperature distribution was small. In winter, the difference between the ceiling and floor of the occupied zone was approximately $1.5^{\circ} \mathrm{C}$, except at 9:00 when the air conditioner was started. It was confirmed in summer and winter that the thermal environment was characterized by a small vertical temperature difference. In the intermediate period, by operating the natural ventilation system at 9:00 at the start of the workday, the temperature of the occupied zone varied vertically between $21^{\circ} \mathrm{C}$ and $25^{\circ} \mathrm{C}$, as early-morning cool air was introduced into the workplace. Afterwards, it stabilized near $25^{\circ} \mathrm{C}$. 


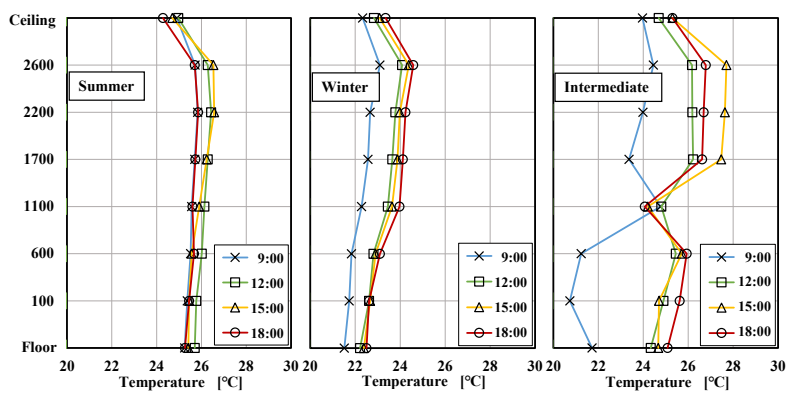

Fig. 14. Vertical temperature distribution in summer, winter, and the intermediate period

\subsubsection{Wind-speed distribution}

Figure 15 shows the average values of the wind-speed distribution in summer, winter, and the intermediate period. The indoor wind speed was less than $0.1 \mathrm{~m} / \mathrm{s}$ in summer and winter. In the intermediate period, by operating natural ventilation under the influence of wind introduced from the outside, the indoor wind speed at the perimeter zone was greater than $0.3 \mathrm{~m} / \mathrm{s}$. However, it may be safely said that there was little influence on work as the perimeter aisle was adopted in the workplace.

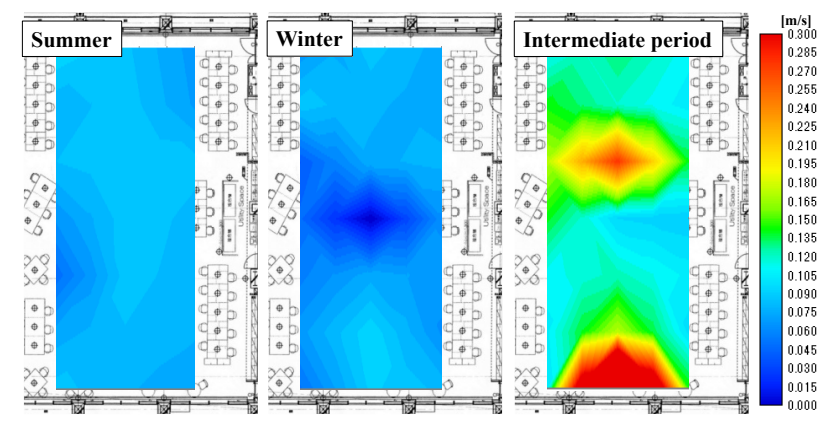

Fig. 15. Mean wind-speed distribution in summer, winter, and intermediate period.

\subsection{Thermal behavior of the skeleton}

\subsubsection{Heat flux of ceiling surface}

Figure 15 shows the heat flux of the ceiling surface in summer. Each figure in section 3.2 expresses ascending heat flux with plus. In summer, with the start-up of the ceiling radiation air-conditioning system at 8:30, the heat flux of ceiling surface gradually increased, while at 17:00, near the end of office hours, the heat flux of ceiling surface reached a maximum at $23 \mathrm{~W} / \mathrm{m}^{2}$. This means that a time-lag occurred for the heat conduction from a cold water pipe.

Figure 16 shows the heat flux of the ceiling surface in winter. Because the workplace had a significant internal heat load, the ascending heat flux of ceiling surface became less than $5 \mathrm{~W} / \mathrm{m}^{2}$.

Figure 17 shows the heat flux of the ceiling surface in the intermediate period by operating the natural ventilation system. The automatic opening and closing windows were opened from 6:00 to 8:00 to introduce cool outdoor air. Meanwhile, the concrete ceiling with large thermal capacity performed heat storage. The heat flux at that time was approximately $10 \mathrm{~W} / \mathrm{m}^{2}$. From 10:00 to $18: 00$, it was confirmed that the heat stored in the concrete ceiling was radiated.

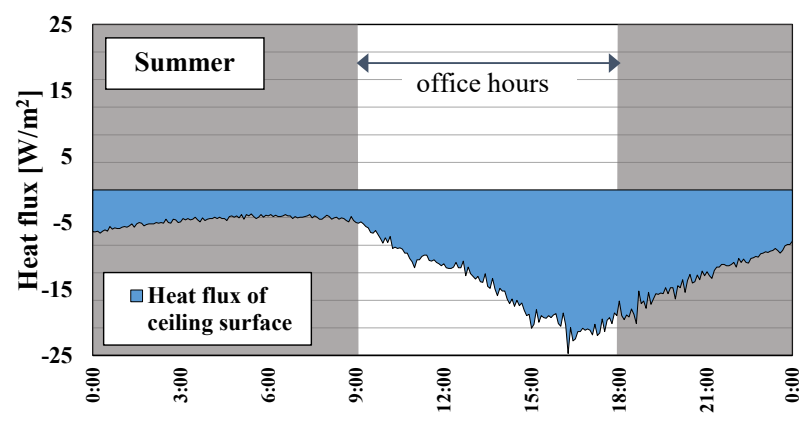

Fig. 15. Heat flux of ceiling surface in summer

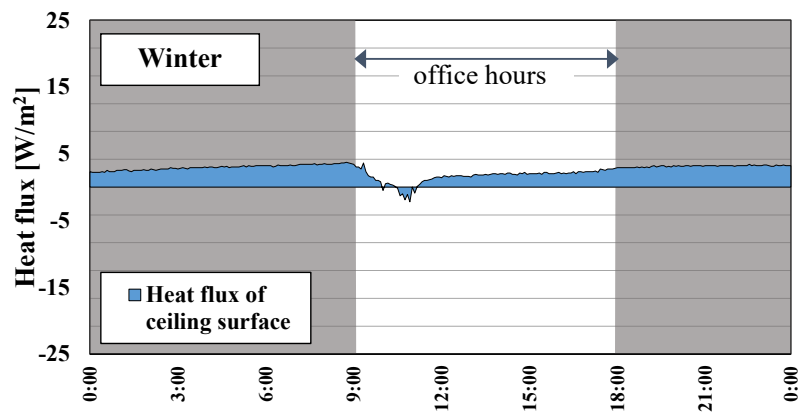

Fig. 16. Heat flux of ceiling surface in winter

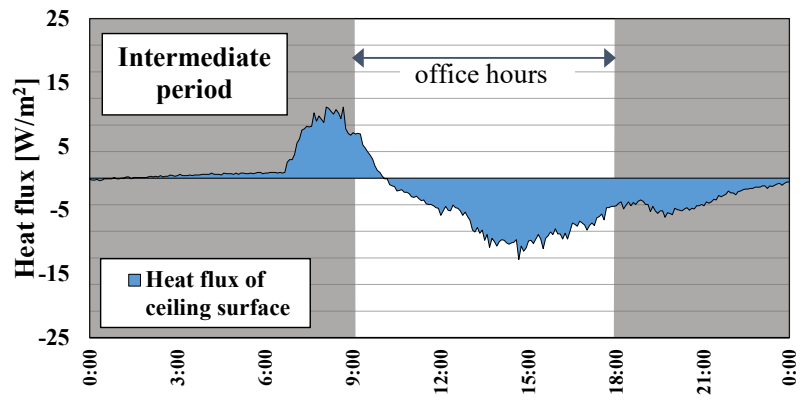

Fig. 17. Heat flux of ceiling surface in intermediate period by operating the natural ventilation system

\subsubsection{Comparison of heat flux between interior and perimeter}

The floor plan of the workplace has a perimeter aisle as a thermal buffer zone. Therefore, the building does not have an air-conditioning system for perimeter zones.

Figure 18 shows the heat flux of the ceiling surface, temperature of the skeleton, and temperature near the ceiling in the west perimeter, interior, and east perimeter. The temperature near the ceiling of the interior stayed near $26{ }^{\circ} \mathrm{C}$ during office hours, that of the east perimeter remained at less than $27^{\circ} \mathrm{C}$, and that of the west perimeter west stayed below $28^{\circ} \mathrm{C}$. The temperature near the ceiling of the perimeter rose because of the heat load from the windows but remained below $28^{\circ} \mathrm{C}$ because the convection heat transfer with the ceiling slab 
skeleton is less than $28^{\circ} \mathrm{C}$. The heat flux of ceiling surface in the east perimeter was $27 \mathrm{~W} / \mathrm{m}^{2}$, and that in the west perimeter was $33 \mathrm{~W} / \mathrm{m}^{2}$ at maximum. In contrast, the heat flux in the interior was approximately $15 \mathrm{~W} / \mathrm{m}^{2}$. The temperature of the skeleton in the perimeter and interior shows the same behavior, and the radiation environment becomes approximately uniform. It may be safely said that the thermal environment of the perimeter is stabilized by the autonomous thermal behavior of the skeleton.
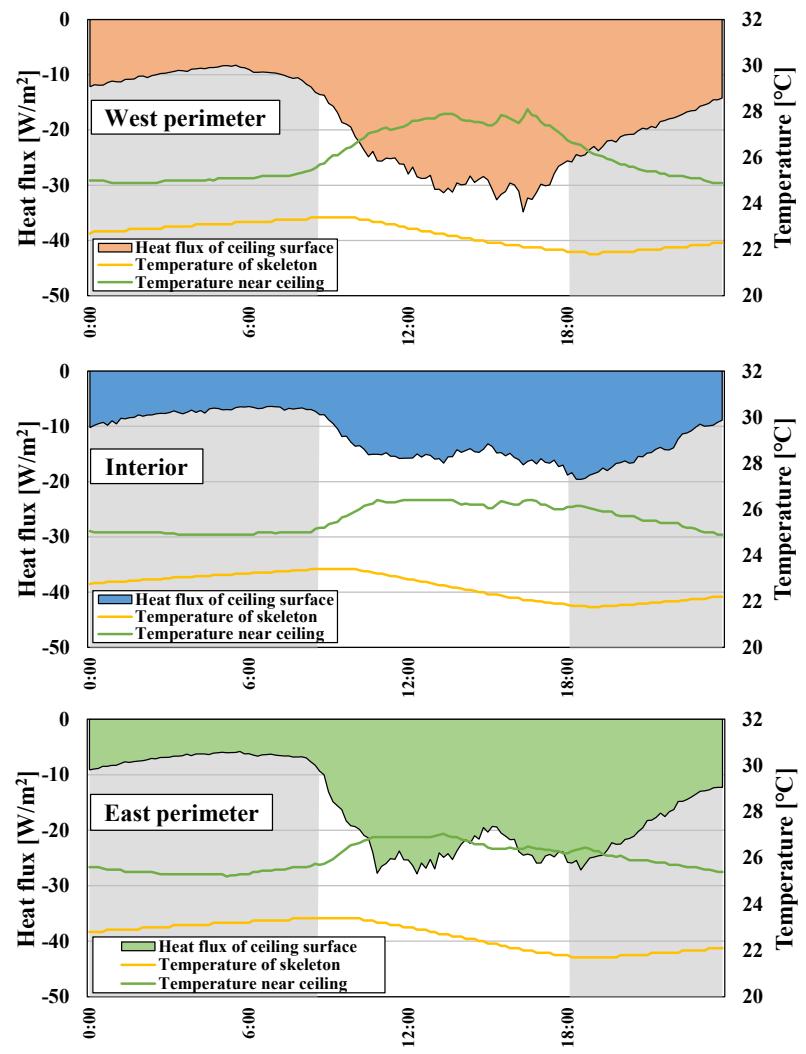

Fig. 18. Heat flux of ceiling surface in west perimeter (upper), interior (middle), and east perimeter (lower)

\subsubsection{Change of heat flux by the operative time moving up}

With the start-up of the ceiling radiation air-conditioning system at 8:30, the heat flux of the ceiling surface reached maximum at 17:00, nearly the end of office hours. This takes place through a time-lag of the thermal behavior of the skeleton. Therefore, the operative schedule for the ceiling radiation air conditioning system was advanced.

Table 4 shows the operative condition of the ceiling radiation air-conditioning system. Case1 refers to office hours, Case 2 is an advance of the office-hour schedule by one hour, and Case 3 is an advance of the schedule by two hours and a one-hour shortening of the operative schedule.

Figure 19 shows the heat flux of ceiling surface for all cases. With Case1, the heat flux of the ceiling surface reached maximum at the end of office hours. With Case2, the heat flux of the ceiling surface reached maximum at
16:00, with the maximum occurring earlier than that of Case1 by two hours. With Case3, the heat flux of the ceiling surface reached maximum at $14: 00$, and the temperature of skeleton declined the most at 10:00. It was confirmed that the maximum of the heat flux of ceiling surface occurs near the middle of office hours when the operative schedule is advanced by two hours.

Figure 20 shows the ratio of heat flow from ceiling surface during office hours to that after office hours. With Case1, this ratio from the ceiling surface during office hours was $55 \%$, and with Case 3 , it was $68 \%$. It was confirmed that the heat flow after office hours was reduced, and the ceiling radiation air conditioning system operated efficiently, thereby suppressing waste of energy.

Table 4. Operative condition of ceiling radiation airconditioning system

\begin{tabular}{|c|l|}
\hline Operative case & Operative schedule \\
\hline Case 1 & From $8: 30$ to $18: 00$ \\
\hline Case 2 & From $7: 30$ to $17: 00$ \\
\hline Case 3 & From $6: 30$ to $15: 00$ \\
\hline
\end{tabular}
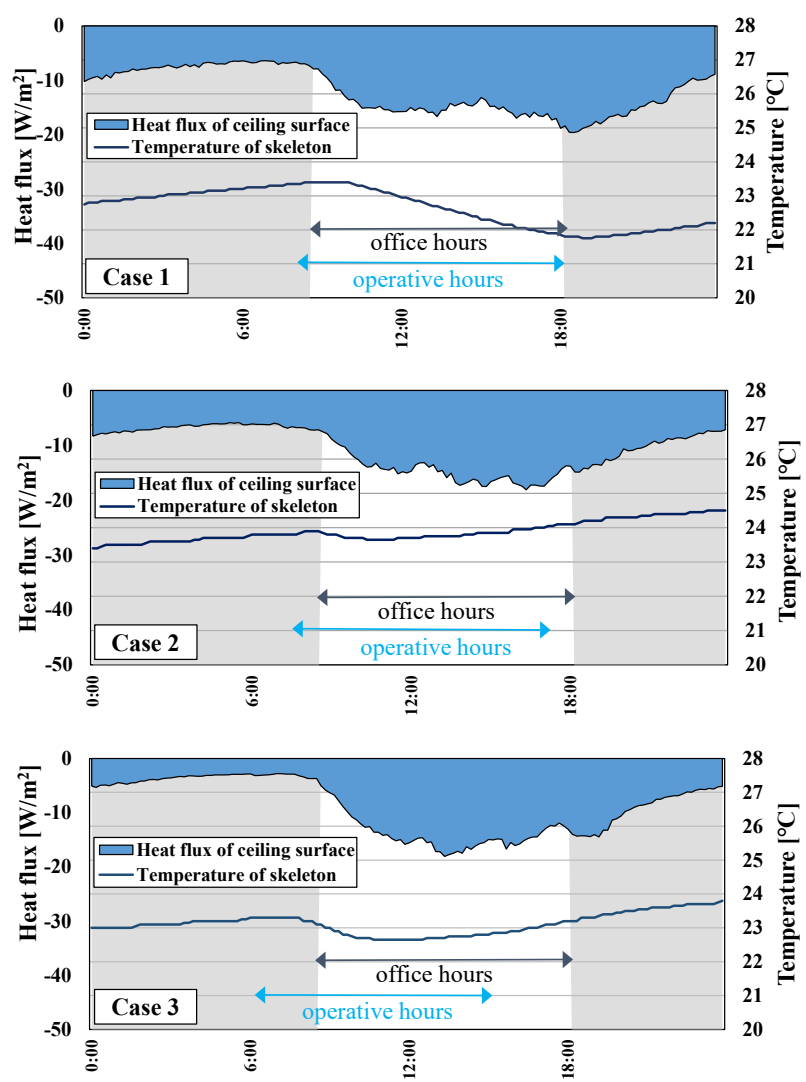

Fig. 19. Heat flux of ceiling surface and temperature of skeleton for all cases. 


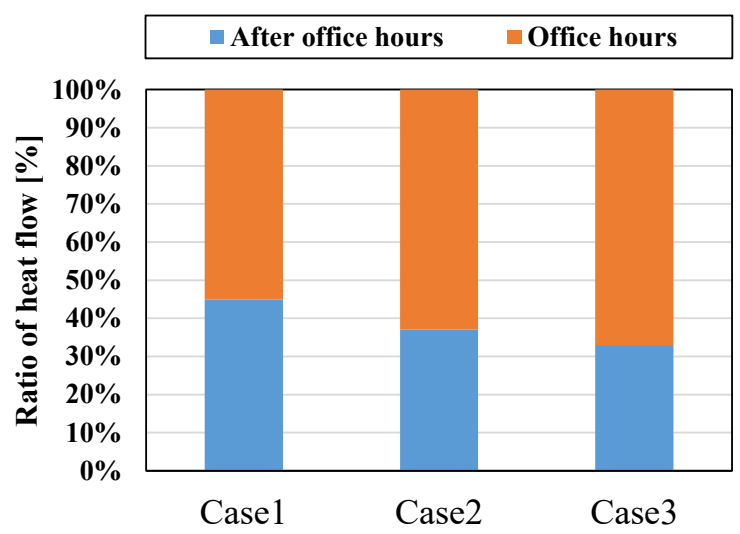

Fig. 20. Ratio of heat flow from ceiling surface during office hours and after office hours.

\section{CONCLUSIONS}

1) A concrete ceiling with a large thermal capacity led to a stable indoor thermal environment in the workplace, and there was little change in the indoor temperature after the air conditioning was switched off.

2) The concrete ceiling with large thermal capacity can perform heat storage of the early-morning cool air by using automatically opening and closing windows.

3) The thermal environment of the perimeter is stabilized by the autonomous thermal behavior of the skeleton in an operating ceiling radiation air conditioning system.

4) A time lag in the heat flux occurs because of the heat behavior of the skeleton in a building with TABS. Heat flow of the ceiling surface after office hours was reduced by advancing the operative schedule by two hours, and the ceiling radiation air conditioning system operated efficiently, thereby suppressing energy waste.

\section{References}

1. H. Muramatsu, et al, Trans. SHASE 254, 71 (2018)

2. B.W. Olesen, ASHRAE J. 44 (2012)

3. R.A. Meierhans, ASHRAE Trans. 99, 511 (1993)

4. R.A. Meierhans, ASHRAE Trans. 102, 693 (1996) 